\title{
The Phenomenon of Terrorism Crime and the Development of Technology in the Perspective of Human Rights
}

\author{
Gracesy Prisela Christy ${ }^{1}$, Lisma Lumentut ${ }^{2}$, Maiercherinra Daud ${ }^{3}$, Dayen Baho ${ }^{4}$ \\ Faculty of Law, Universitas Kristen Indonesia Paulus ${ }^{1,2}$, Faculty of Economics and Business, \\ Universitas Kristen Indonesia Paulus ${ }^{3}$, Faculty of Law, Universitas Kristen Indonesia Sorong ${ }^{4}$ \\ \{gpchristy@ukipaulus.ac.id ${ }^{1}$ \}
}

\begin{abstract}
Combating terrorism is closely related to the concept of upholding and protecting human rights in a democratic country. The issue of terrorism has become a transnational issue that threatens world peace, therefore comprehensive efforts are very important for the government to overcome this problem both legally, formally, institutionally and practically. The purpose of this research is to harmonize the implementation of regulations on terrorism from a human rights perspective, because it is still a pros and cons in Indonesian society. The writing of this article uses normative legal research methods. The results showed that the Indonesian government had effective regulations in dealing with criminal acts of terrorism; also regarding the content of the material on various articles listed in Law no. 5 of 2018 is still not fully in line with the principles and norms of human rights which result in the potential or threat of human rights violations, criminal acts of terrorism are increasingly developing with technological advances that are currently spreading into social life.
\end{abstract}

Keywords: terrorism; technology; human rights

\section{Introduction}

Etymologically, terrorism comes from the Latin word "terrere" which means "to frighten" which was absorbed into French and then first used in English in 1528. Terrorism itself does not have a standard term and is used universally. This is because terrorism can be seen from a variety of scientific perspectives such as criminology, political science, defense and security, international relations, communication, religion, and others. Because of this, the study of Terrorism is multidisciplinary, so that if it is defined, terrorism is considered a form of crime, a form of political violence, a form of war strategy, and a form of communication.

The difficulty in agreeing on a definition related to terrorism results in the deprivation of human rights of citizens, this is due to multiple interpretations because there is no standard definition of terrorism. The UN Special Rapporteur on Freedom of Expression and Opinoin states that "Many Governments use anti terrorism and national security legislation to restrict, partially or totally, fredom of opinion and expression and the right to access information". The 
same statement was issued by the UN High Commissioner for Human Rights which noted that states have an obligation to protect everyone from acts of terrorism, but many efforts to prevent and eradicate terrorism have been used to reduce voices from human rights defenders, journalists, minority groups, the public. adat, and also civil society.

In order to avoid confusion in the international legal constellation regarding the intersection of human rights and terrorism, the UN Security Council appointed a special rapporteur named U.N. Special Rapporteur on the Promotion and Protection of Human Rights and Fundamental Freedoms While Countering Terrorism which works under the mandate of Resolution 2005/80 of the UN Human Rights Commission and strengthened by Resolution $60 / 251$ of the UN Human Rights Council. In the context of Indonesia, various terrorism incidents have implications, both directly related to the emergence of fear, material loss, and casualties and injuries, or vulnerability to the spread of radicalism and terrorism, especially for the younger generation and women as stated by the National Counterterrorism Agency. (BNPT) The public also considers that terrorism is a threat to the life of the state and the integrity of the Unitary State of the Republic of Indonesia (NKRI), and condemns / condemns acts of terror regardless of motives (ideology, politics, religion, etc.) these acts are considered heinous and injure humanity.

Social media also resonates with solidarity and our hashtag (\#) has no fear and love for Indonesia. Meanwhile, from the government, the People's Representative Council (DPR) and the Police see that the law enforcement instrument is through the regulation of Law no. $15 / 2003$ concerning the Eradication of Criminal Acts of Terrorism, is considered inadequate in eradicating criminal acts of terrorism with various modifications of forms of attacks, targets and groups of perpetrators

This phenomenon is what then makes the momentum for the discussion of the revision of Law no. 15/2003 concerning the Eradication of Criminal Acts of Terrorism which has dragged on between the Government and the DPR. Through the DPR Plenary Session on May 25/2018, the Government and the DPR agreed (approved) the revision of the Law, and then on June 21/2018 the President passed Law No. 5/2018 concerning Amendments to Law No. 15/2003 concerning Stipulation of Government Regulations in Lieu of Law No. 1/2002 concerning Eradication of Criminal Acts of Terrorism into Law (Law No.5/2018). This acceleration was carried out after two years of discussion stopped without any agreement regarding the content of the material. The government and the DPR, through the effort to reform this regulation, view that acts of terrorism have become a serious crime and at the stage endanger ideology, security, sovereignty, human values, as well as various aspects of social life, nation and state, are transnational, organized, and have a wide network. and has a specific purpose so that its eradication needs special treatment.Therefore, the urgency of the formation of Law no. $5 / 2018$ is intended to provide a stronger legal basis in the efforts to eradicate criminal acts of terrorism in Indonesia. In addition, it is also aimed at meeting the needs and legal developments in society. To ensure fair enforcement, Law no. 5/2018 seeks to proportionate the concept of human rights, socio-political conditions, and law enforcement itself. After the revision was made, in just a matter of months there were massive arrests of suspected terrorists. UU no. 5/2018 becomes the legitimacy for the National Police to arrest 242 suspected terrorists after the bombing incident in May 2018. The purpose of this study is to harmonize the application of regulations against terrorism crimes from a human rights perspective, because this is still a pros and cons in society in Indonesia, as well as encouraging law enforcement to eradicate terrorism crimes to remain based on the due process of law highly upholds human rights and characterizes the paradigm of the cirminal justice system in order to avoid excessive acts of violations, especially with military involvement. 
Based on the description above, this paper seeks to find out the extent of the alignment between the application of the rules against the crime of terrorism from a human rights point of view, because this is still the pros and cons of society in Indonesia, as well as encouraging law enforcement to eradicate the crime of terrorism. based on due process of law which highly upholds human rights and characterizes the paradigm of the legal justice system in order to avoid excessive acts of violations, especially with military involvement.

\section{Methodology}

This type of research is normative legal research. Then, the approach method applied to discuss research problems is through a philosophical approach and a conceptual approach. Types and sources of data used as research material are primary data, namely data obtained from documentation studies. Secondary data is data obtained from researching scientific literature and laws and regulations relating to the object of research. After the required data, both primary data and secondary data, will be processed first and then analyzed descriptively qualitatively, namely descriptions according to quality that prevail in reality as a symptom of primary data that is linked to theories in secondary data relating to writing this journal.

\section{Result and Discussion}

One of the POLRI's duties is to enforce the law, especially criminal law. Enforcement of criminal law on the technical side is related to the implementation of criminal procedural law, which regulates how material criminal law is implemented, including the rights of suspects and victims. The police are at the forefront of criminal law enforcement, so it is not an exaggeration to say that the police are a living criminal law. In Article 4 of the POLRI Law, it is emphasized that the State Police of the Republic of Indonesia aims to realize domestic security which includes the maintenance of public security and order, order and upholding of the law, the implementation of protection, protection and services to the community, as well as maintaining public peace by upholding rights. human rights. This means that law enforcement in addition to protecting human rights, also at the same time upholding human rights itself. Even though there are 2 (two) interrelated sides, its implementation is not easy When faced with an emergency that can endanger the community or apparatus. So it is very possible that law enforcement is carried out in fact. They are considered to have violated human rights. Moreover, the position of the police in enforcing criminal law is known as a double-edged sword, that is, it can be both a protector and an attack on human rights due to their power of force, acts of violence and even weapons.

The use of force by the police is a piece of equipment or part of the equipment to be able to carry out their work, namely building and maintaining order in society. This fuzzy and vague definition of violence has the potential to lead to abuse of authority and human rights violations. The international community seems to be fully aware of certain conditions or emergencies through MU-UN Resolution 34/169 dated 17 December 1979 concerning "Code of Conduct for Law Enforcement Officials", which allows law enforcement officials to use force as a force. excessive action in carrying out its duties and the 8/1990 UN Congress on "the Prevention of Crime and the Treatment of Offenders" which has received the "Basic Principles on the Use of Force and Firearms by Law Enforcement Officials". 
In the "Basic Principles", it is stated that there are general provisions and special provisions that must be considered by the government / member countries in drafting a national legislative pattern and in its implementation practice. General provisions consist of 10 of 8 (eight) principles. , that is :The government can implement the rules for the use of "Force and Firearms" by law enforcement officials.b. The government and law enforcement officials should develop the widest possible equipment or facilities and equip them with a variety of weapons and ammunition for different uses. This includes developing non-lethal weapons and increasing control over the use of tools that can cause death or injury.c. The development of nonlethal weapons should be carefully evaluated to minimize the risk of harm to others and their use should be monitored carefully or carefully.d. Before using force and firearms, law enforcement officials should use non-violent means as far as possible. They are allowed to use force and firearms only when other means are ineffective or those other means do not promise to achieve the intended results.Indonesia, based on the provisions of Article 1 paragraph (3) of the 1945 Constitution of the Republic of Indonesia (UUDN RI 1945), declares itself a rule of law. The implication is that the overall social relations system, both public and private, is based on legal instruments, especially in countries with a civil law tradition that makes written law a reference. Thus, all forms of legislation that are formed aim to regulate (public order) people's lives in a better direction, including in the context of this discussion in the handling of criminal acts of theory.

In order to obtain a good legal product, a clear concept is needed which must have a basis and groundnorm which mainly emphasizes the aspects of justice. Its formation must also be based on a legislative hierarchy and pay attention to the principles that are in accordance with the basis of its formation. Thus, this principle will become a basis (baseline) in determining attitudes, behavior and

material content in the formation of laws and regulations. Formally in Law no. 12 of 2011 concerning the Formation of Laws and Regulations through the provisions of Article 6 paragraph (1) has stipulated that the material content in each product of statutory regulations must reflect various principles, including protection, humanity, nationality, kinship, nationality, diversity, justice, equality. in law and government, order and legal certainty, balance, harmony and harmony.

Especially with regard to humanitarian principles, based on the provisions of the explanation of Article 6 paragraph (1) letter b of Law no. 12 of 2011 explains that: "what is meant by the principle of humanity, namely that every material contained in statutory regulations must reflect the protection and respect for human rights, as well as the dignity and worth of every citizen and population of Indonesia proportionally". This provision is also the mandate of Article 28I paragraph (5) of the 1945 Constitution of the Republic of Indonesia which stipulates that in order to uphold and protect human rights in accordance with the principles of a democratic rule of law, the implementation of human rights is guaranteed, regulated. and regulated in statutory regulations. Thus, it is clear that in the constitutional structure and legislative policies, the principles and norms of human rights must become one of the main guidelines (foundations) that animate the formation of legislation products.

There is a new conception in the provisions of Article 31, especially paragraph (1) letter b of Law no. 5 of 2018 which authorized the interception (wiretapping) of investigators. The authority is given in two aspects, namely (a) law enforcement by tapping conversations by telephone or other means of communication allegedly being used to prepare, plan and carry out criminal acts of terrorism; (b) intelligence function to monitor the whereabouts of perpetrators who are suspected of being involved and / or developing terrorist networks. From a human rights perspective, wiretapping is generally categorized as a prohibited act because it 
violates the right to privacy, both through international and domestic law. The prohibition is based on the provisions of Article 12 of the Universal Declaration of Human Rights (UDHR) 1948 which states: "No one shall be subject to arbitrary interference with his privacy, family, home or correspondence, or to attack on the honor and honor of his reputation. Everyone reserves the right to legal protection against such interference attacks ". This formulation was then reaffirmed in Article 17 of the ICCPR which Indonesia ratified through Law no. 12 of 2005, and General Comment No. 16 concerning Article 17 of the ICCPR; furthermore based on the provisions of Article 28F of the 1945 Constitution and Article 32 of Law no. 39 of 1999 which states that: "Freedom and confidentiality in correspondence, including communication via electronic means, may not be disturbed, except at the order of a judge or other legal power in accordance with the provisions of laws and regulations". The conception of this regulation was strengthened by the Constitutional Court through decision Number 5 / PUU-VIII / 2010 regarding judicial review (testing).

Tapping in Law no. 11 of 2008 concerning Information and Electronic Transactions, as well as Decree No. 006 / PUU-I / 2003 concerning Review of Law No. 30 of 2002 concerning the Corruption Eradication Commission, which in its decision states that tapping is a violation of human rights, but since the right to freedom is part of a right that can be reduced, its fulfillment can be limited (reduced) based on legal interests. . . However, Article 28J paragraph (2) of the 1945 Constitution requires that the limitation of human rights must be regulated in statutory regulations at the legal level and in accordance with the level of threats faced. Thus, wiretapping within the framework of lawful interception, including handling of criminal acts of terrorism, can be held accountable by the state through its law enforcement officials. William A Schabas in An Introduction on the International Criminal Court emphasized that tapping in the dimension of international criminal law is part of lex, especially as part of the core crime, which consists of (a). gross violations of human rights; (b) genocide; (c). war crimes; (d). crimes against humanity, (e) acts of aggression. Then, nowadays tapping has developed into terrorism and transnational organized crime. Although wiretapping within the framework of law enforcement can be carried out, such restrictive measures must still refer to the human rights standards set out in the Siracusa Principles on the Limitation and Derogation of Provisions in the International Covenant on Civil and Political Rights, which are based on 5 (five) criteria. or reasons, namely:

It is determined by law and cannot be determined arbitrarily, must meet the element of fairness, establish clear and accessible limitations, and regulate mechanisms for the protection and recovery of victims ,In a democratic society, the regulation of limiting rights carried out by the government must not destroy the democratic order that has been built. ,Considerations for the sake of public order, the context must be linked to the objectives of the fulfillment, protection and enforcement of human rights so that they cannot be arbitrarily interpreted by the authorities, and organs that have restrictive authority must be subject to supervision through parliament, judiciary or independent bodies. ,Considerations to fulfill public morals, because the nature and moral standards of the public vary, the restrictions that are made must be based on basic human values and not be discriminated against on any basis of justice; and In the interest of national security, in special conditions the limitation of certain rights can be limited to protect the nation and its territorial integrity.

3.1 Deviations of Human Rights in the Era of Democracy in Facing the Phenomenon of Terrorism 
The state of Indonesia is a state of law or rechtstaats, one of the characteristics of the recognition and protection of human rights contained in the constitution. On the other hand, demands for human rights are very high in relation to freedom of access to information through globalization. However, these developments have also contributed to the ease of relations between world terrorism networks and national networks. In addition, developments in the conditions of each country also affect the root causes of terrorism. At the $2001 \mathrm{UN}$ General Assembly, representatives of UN member states revealed the root causes of terrorism in their respective countries. Armenia, for example, claims the cause of terrorism is poverty. Meanwhile, the countries of Benin, Costa Rica, Dominican Republic, Finland, Malaysia, Palestine, and other Namibia state that terrorism arises because of social inequality, marginalization, oppression, violations of basic rights, injustice, misery, hunger, drugs, social prejudice, the alienation of young people in Indonesia. Amid a situation of economic decline and political instability, rejection of the West with all its cultural aspects, fear and despair. However, if we look back, the development of terrorism today is that terrorism is often associated with belief in a religion in the motives behind it.

It is agreed by Bruce Hoffman that "the religious imperative of terrorism is the most important characteristic of current terrorist activity". However, some experts disagree that religion is the reason behind acts of terrorism. Robert Pape emphasized that political motives always underlie acts of terrorism, religion is only the innocent victim of hardline groups. Furthermore, the thing that drives the development of terrorism is globalization. Globalization facilitates the motivation and ideology for acts of terrorism.Paul R. Pillar stated, that in today's world that we cannot avoid from globalization, terrorists can very easily target their targets with easy access to communication and information. In addition, thanks to easy access to information and communication, news and ideas related to Terrorism can be spread easily compared to ancient times. In addition, the root causes of the emergence of terrorism are also the result of a country's foreign policy activities. According to Savun and Philips, countries that have certain foreign political activities tend to have more potential to attract transnational terrorism, especially those that have very active foreign political activities.

This situation is an anomaly in the era of democracy, where the development of globalization is increasingly unstoppable and demands for respect for human rights are also getting bigger. Human rights slices always enter and sometimes make it difficult for the government to move to prevent the seeds of terrorism. According to Prof. Romli Atmasasmita, S.H., LL.M, there are two aspects to eradicating terrorism, namely the national aspect and the global aspect. Where the national aspect prioritizes preventive, preemptive and repressive efforts as well as global efforts in the form of comprehensive cooperation to tackle the movement of terrorism between countries. This is important for a democratic country to do, considering (1) democracy and political freedom are incomplete if they do not feel safe. Whereas the reform movement aims to make us safe in our own country; (2) terrorism is a crime against humanity in an organized form.

Indonesia through Law no. 5 of 2018 , conceptually and paradigmatically consistently choose to become a civilized country by placing the law as commander in chief. This paradigm is reflected in the application of the conception of the Criminal Justice System (CJS) which emphasizes the principles of law enforcement and processing perpetrators through the courts. In the view of Al Araf, Director of Imparsial, this must be supported as a concrete manifestation of Indonesia maintaining the principles of a rule of law that upholds human rights.

\subsection{Human Rights Oriented Combating Terrorism}


The Special Detachment 88 Team in enforcing law through eradicating terrorism in the context of upholding human rights. In Article 2 of Law Number 15 of 2003 it is emphasized that the eradication of criminal acts of terrorism is a policy and strategic step to strengthen public order and public safety while upholding law and human rights, non-discrimination, based on ethnicity, religion, race, or between groups. To realize this and be guided by the Basic Principles, guidelines are needed in carrying out POLRI duties that are human rightsoriented, including the eradication of terrorism.

Chief of Police Regulation Number 8 of 2009 concerning the Implementation of Human Rights Principles and Standards in the Implementation of POLRI Duties, basically can serve as a guide, reference and signpost for every member of the National Police, including Densus 88 in carrying out their duties in the field. Article 2 paragraph (2) of this Regulation of the National Police Chief states the objective, namely to ensure that all levels of Polriagar have an understanding of the basic principles of human rights in carrying out their duties by always paying attention to human rights principles; ensure that there is a change in mindset, behavior and action in accordance with the basic principles of human rights; ensure the application of human rights principles and standards in all Polri duties, so that every INP member does not hesitate to act; and serve as a guideline in the formulation of Polri policies so that they are always guided by human rights principles and standards. Article 3 affirms the principles of protecting human rights, including:A. minimal protection;b. attached to humans;c. interconnected;d. can not be separated;e. cannot be divided;f. universal;g. the basics; $h$. justice;me. equality / equal rights; j. freedom;k. without discrimination; andl. special treatment for groups with special needs (affirmative action)

\section{Conclusion}

Based on the description above, it can be concluded that the eradication of terrorism is closely related to the concept of upholding and protecting human rights in a democratic country. The issue of terrorism has become a transnational issue that threatens world peace, therefore comprehensive efforts are very important for the government to overcome this problem both legally, formally, institutionally and practically. The purpose of this study is to harmonize the implementation of regulations on criminal acts of terrorism from a human rights perspective, because it is still a pros and cons in Indonesian society. The writing of this article uses normative legal research methods. The results showed that the Indonesian government had effective rules in dealing with terrorism crimes; also regarding the content of the material in various articles listed in Law no. 5 of 2018 is still not fully in line with the principles and norms of human rights which result in the potential or threat of human rights violations, terrorist crimes are increasingly developing with the advancement of technology which is currently spreading into everyday life.

\section{Acknowledgment}

The author expresses his appreciation to Paulus Indonesian Christian University for supporting the publication of this article.

\section{References}


[1] Suntoro, A., 2020. Penerapan Asas dan Norma Hak Asasi Manusia dalam UndangUndang Pemberantasan Tindak Pidana Terorisme (The Application of Human Rights Principles and Norm in the Law on Combating Criminal Acts of Terrorism). Negara Hukum: Membangun Hukum untuk Keadilan dan Kesejahteraan, 11(1).

[2] Golda Eksa, 21 Januari 2019, "Terorisme Ancaman Nyata yang Memengaruhi Keutuhan Bangsa", https:// mediaindonesia.com/read/detail/211901-terorismeancamannyata-yang-memengaruhi-keutuhan-bangsa, diakses tanggal 29 oktober 2020.

[3] Adi Priyanto Utomo, 22 April 2019, "Kami Tidak Takut, Kami Tidak Akan Membiarkan Teroris Itu Menang", https:/internasional.kompas.com/ $\mathrm{read} / 2019 / 04 / 22 / 12161111 /$ kami-tidak-takut-kami-tidakakan-membiarkan-teroris-itumenang, diakses tanggal 17 April 2020.

[4] Sistem Informasi Peraturan Perundang-Undangan Sekretariat Kabinet, 22 Juni 2018, https://sipuu.setkab. go.id/PUUdoc/175528/UU\%20No. \%205\%20Tahun\%20 2018.pdf, diakses tanggal 17 April.

[5] Farhan, M.A. and Heniarti, D.D., 2019. Keterlibatan TNI dan Polri dalam Penanggulangan Tindak Pidana Terorisme berdasarkan Undang-Undang Nomor 5 Tahun 2018 tentang Perubahan Atas Undang-Undang Nomor 15 Tahun 2003 tentang Perubahan Penetapan Peraturan Pemerintah Pengganti Undang-2020Undang Jo. Undang-Undang Nomor 1 Tahun 2002 tentang Pemberantasan Tindak Pidana Terorisme.

[6] Bagian Umum Paragraf 8 Penjelasan Atas UU No. 5 Tahun 2018 tentang Perubahan atas Undang-Undang No. 15 Tahun 2003

[7] Arief, B.N., 2009. Kumpulan Hasil Seminar Hukum Nasional Ke I s/d VIII dan Konvensi Hukum Nasional 2008. Semarang: Pustaka Magister Semarang

[8] Rahardjo, S., 2002. Polisi sipil dalam perubahan sosial di Indonesia. Penerbit Buku Kompas.

[9] Rahardjo, S., 2009. Penegakan Hukum: Suatu Tinjauan Sosiologis. Genta Pub

[10] Arief, B.N., 1998. Beberapa aspek kebijakan penegakan dan pengembangan hukum pidana. Citra Aditya Bakti

[11] Febriansyah, F.I., 2016. Konsep pembentukan peraturan perundang-undangan di Indonesia. Perspektif: Kajian Masalah Hukum dan Pembangunan, 21(3), pp.220-229.

[12] Alam, N., 2017. Konstitusionalitas Penyadapan (Interception) Dengan Peraturan Pemerintah Dari Sudut Pandang Perlindungan Hak Asasi Manusia. Jatiswara, 27(3)

[13] Thontowi, J., 2015. Penyadapan dalam Hukum Internasional dan Implikasinya terhadap Hubungan Diplomatik Indonesia dengan Australia. Jurnal Hukum Ius Quia Iustum, 22(2), pp.183-202.

[14] Principles, S., 1985. The Siracusa Principles on the Limitations and Derogation Provisions in the International Covenant on Civil and Political Rights. Human Rights Quarterly, 7(1), pp.3-14.

[15] Schmid, A.P., 2013. Radicalisation, de-radicalisation, counter-radicalisation: A conceptual discussion and literature review. ICCT Research Paper, 97(1), p.22.

[16] Gunaratna, R., 2008. Bruce Hoffman: Inside Terrorism: (New York, Columbia University Press, 2006).

[17] Junaid, H., 2013. Pergerakan Kelompok Terorisme dalam Perspektif Barat dan Islam. Sulesana: Jurnal Wawasan Keislaman, 8(2), pp.118-135.

[18] Pillar, P.R., 2001. Terrorism goes global: Extremist groups extend their reach worldwide. The Brookings Review, 19(4), pp.34-37.

[19] Savun, B. and Phillips, B.J., 2009. Democracy, foreign policy, and terrorism. Journal of 
Conflict Resolution, 53(6), pp.878-904.

[20] Firmansyah, H., 2011. Upaya Penanggulangan Tindak Pidana Terorisme di Indonesia. Mimbar 